\title{
PENDAMPINGAN PENULISAN ARTIKEL ILMIAH BAGI GURU-GURU SMA KECAMATAN JALAKSANA KABUPATEN KUNINGAN
}

\author{
Sumarni ${ }^{1)}$ Anggar Titis Prayitno ${ }^{2)}$ Nuranita Adiastuty ${ }^{3)}$ \\ ${ }^{1,2,3)}$ Program Studi Pendidikan Matematika, Fakultas Keguruan dan Ilmu Pendidikan, Universitas Kuningan \\ 1) e-mail :sumarni@uniku.ac.id
}

\begin{abstract}
Abstrak
Salah satu wujud pengembangan keprofesianalan guru adalah menulis artikel ilmiah dan publikasi artikel ilmiah. Oleh karena itu, hendaknya guru terus belajar menulis artikel ilmiah untuk diseminarkan maupun dipublikasikan di jurnal. Kenyataan di lapangan menunjukkan bahwa sebagian besar guru belum mampu menghasilkan dan melakukan publikasi ilmiah. Tujuan kegiatan pengaabdian ini adalah meningkatkan motivasi dan kemampuan guru dalam menulis artikel ilmiah dari hasil penelitian yang dapat digunakan sebagai salah satu persyaratan pengajuan kenaikan pangkat sehingga berdampak juga terhadap profesionalitas guru. Kegiatan pengabdian yang dilaksanakan menggunakan metode ceramah, tanya jawab dan simulasi. Kegiatan pelatihan penulissan artikel ilimah yang telah dilaksanakan dapat meningkatkan motivasi guru untuk menulis artikel ilmiah; guru memiliki pengetahuan dan kemampuan memilih tempat publikasi yang sesuai; guru memiliki pengetahuan tentang cara mencari sumber refrensi mutakhir melalui google scholar; guru memiliki pengetahuan tentang trik untuk publikasi artikel ilmiah hasil penelitian; guru dapat mengetahui bagaimana membuat draft artikel ilmiah hasil penelitian sesuai dengan tamplate jurnal yang dituju; seluruh peserta pelatihan memiliki pandangan positif terhadap pelatihan penulisan artikel ilmiah dan memandang tingkat kebermanfaatan pelatihan pada tingkat bermanfaat dan sangat bermanfaat.
\end{abstract}

Kata Kunci: artikel ilmiah, guru SMA, profesionalisme guru.

\begin{abstract}
One form of teacher professional development is writing scientific articles and publishing scientific articles. Therefore, teachers should continue to learn to write scientific articles to be disseminated or published in journals. The reality on the ground shows that most teachers have not been able to produce and do scientific publications. The purpose of this service activity is to increase the motivation and ability of teachers to write scientific articles from the results of research that can be used as one of the requirements for submission of promotions so that it also impacts on teacher professionalism. Community service activities carried out using lecture, question and answer and simulation methods. Scientific article writing training activities that have been implemented can increase the motivate teachers to write scientific articles; the teacher has the knowledge and ability to choose a proper place of publication; the teacher has knowledge of how to find the latest sources of reference through google scholar; the teacher has knowledge of tricks for publishing scientific articles on research results; the teacher can know how to make a draft scientific article based on the results of the intended research template; all trainees have a positive view of the training in writing scientific articles and see the level of usefulness of the training at the level of useful and very useful.
\end{abstract}

Keywords: scientific articles, high school teachers, teacher professionalism.

\section{PENDAHULUAN}

Salah satu wujud pengembangan keprofesian guru adalah dengan menulis karya ilmiah. Guru wajib memenuhi syarat berupa penulisan karya tulis ilmiah baik berupa penelitian tindakan kelas ataupun artikel yang dipublikasikan dalam seminar atau jurnal (Mawardi, dkk, 2019). Menurut Noorjannah
(2014) secara umum pengembangan profesionalisme guru SMA dalam penulisan karya tulis ilmiah masih kurang dan perlu mendapatkan perhatian dan bimbingan secara serius. Samuel (2012) menyarankankan bahwa guru hendaknya terus belajar dan menulis baik karya ilmiah maupun populer untuk diseminarkan maupun dipublikasikan 
di media massa sebagai bentuk pengembangan profesionalismenya. Berdasarkan rambu-rambu dalam Permen PAN dan RB No. 16 Tahun 2009 tentang Jabatan Fungsional Guru dan Angka Kreditnya ditentukan "bahwa salah satu kegiatan pengembangan profesi adalah publikasi ilmiah". Menurut Daryanto (2013) melalui sistem angka kredit diharapkan dapat diberikan penghargaan secara lebih adil dan lebih profesional terhadap pangkat guru yang merupakan pengakuan profesi dan kemudian akan meningkatkan tingkat kesejahteraannya. Angka kredit tersebut dapat digunakan untuk kenaikan pangkat/golongan bagi guru. Mulai tahun 2013 aturan itu diberlakukan bagi kenaikan pangkat mulai III b, sedangkan sebelumnya hanya untuk kenaikan pangkat mulai IVa..

Adanya peraturan di atas menunjukkan bahwa pemerintah sudah berusaha memotivasi guru untuk menulis melalui pemberian angka kredit sebagai syarat kenaikan pangkat/golongan. Penulisan karya Ilmiah selain menjadi syarat bagi pengembangan karir, menulis juga menjadi sarana bagi pengembangan diri seorang guru (Mawardi, dkk., 2019). Akan tetapi, kenyataan di lapangan menunjukkan bahwa sebagian besar guru belum mampu menghasilkan dan melakukan publikasi ilmiah. Hal ini sesuai dengan pernyataan Mujiwati, dkk (2017) yang mengemukakan bahwa Syarat ini (publikasi ilmiah) seringkali menjadi penghambat kenaikan jenjang pangkat bagi guru mengingat rendahnya kemampuan dan minat menulis di kalangan guru.

Contoh kasus ini terjadi pada salah satu guru matematika di Kuningan, yang berusaha mempublikasikan hasil penelitiannya pada jurnal di prodi pendidikan matematika UNIKU. Editor mengklarifikasi format penulisan yang belum sesuai dengan tamplate Jurnal. Reviewer memberikan saran untuk perbaikan terhadap artikel yang ditulis oleh guru tersebut diantaranya penulisan hasil penelitian pada abstrak yang seharusnya tidak ada angka-angka hasil penelitian; bagian pendahuluan yang tidak memaparkan permasalahan; tidak ditunjang hasil sintesis penelitian terdahulu; ada ketidaksesuan antara teknik pengumpulan data dengan data yang dipaparkan di hasil dan pembahasan; pembahasan yang belum dikaitkan dengan teori ataupun hasil penelitian terdahulu; dan masih minimnya refrensi artikel jurnal.

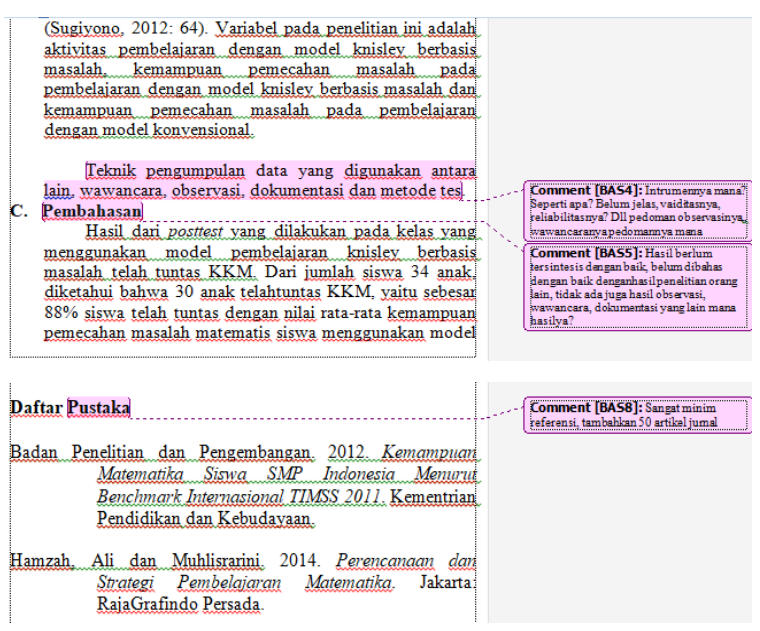

Gambar 1. Contoh bagian artikel hasil karya guru

Setelah hasil review diinformasikan kepada guru dan diberikan waktu untuk perbaikan, dalam waktu yang ditentukan guru tersebut tidak mengirimkan hasil perbaikan artikel sesuai saran reviewer. Setelah diklarifikasi guru tersebut mengalami kendala dalam perbaikan artikel alasan banyak tugas di sekolah yang harus dikerjakan, kesulitan dalam pencarian sumber referensi jurnal. Berdasarkan hasil wawancara, guru tersebut harapannya artikelnya langsung terbit tanpa harus melakukan perbaikan. Karena keterbatasan kemampuan guru dalam menulis, pada akhirnya guru menggunakan jasa pembuatan artikel ilmiah. Hal tersebut juga ternyata dialami oleh sebagian besar guru di Kuningan. Berdasarkan hassil wawancara dengan 3 orang guru di salah satu SMA di Kecamatan Jalaksana, ketiganya mengatakan bahwa karena keterbatasan waktu luang, lebih fokus ke tugas mengajar, administrasi dan struktural serta keluarga, kurangnya pemahaman terhadap penulisan artikel ilmiah ketiganya lebih lebih memilih "terima jadi".

Hal tersebut sejalan dengan hasil penelitian Supriyanto (2015) yang menyatakan bahwa: kendala yang dialami guru dalam menulis karya ilmiah meliputi: (a) motivasi menulis yang rendah, (b) tidak memiliki cukup waktu luang, (c) kurangnya pemahaman tentang teknik penulisan, (d) kesulitan mencari data, (e) gagap teknologi, (f) tidak memiliki buku referensi, (g) maraknya jasa pembuatan karya 
tulis, (h) kurang berfungsinya kegiatan kelompok kerja guru (KKG) dalam meningkatkan kompetensi menulis karya ilmiah, (i) kurangnya dukungan dari sekolah.

Rintaningrum (2018) Memaparkan alasan mengapa guru tidak menulis sebagai berikut. 1) Waktu sudah tersita untuk banyaknya pekerjaan guru (beban) sebagai guru kelas, mendidik siswa di sekolah, dan juga karena memberikan bimbingan bagi siswa di luar kelas; 2) bingung mau menulis apa, kurang ide untuk memulai menulis; adanya rasa malas untuk menulis; 3) kurang memiliki kemauan (motivasi) untuk menulis; 4) kurang memahami ilmu menulis yaitu belum paham cara menulis karya tulis ilmiah, 5) minimnya literature yang dijadikan referensi menulis; 6) terlalu banyak revisi dan berulang-ulang dari pembimbing yang tanpa memberikan arahan yang konkret, sehingga bimbingannya menjadi bertambah bingung.

Guru yang kompeten sangat menjamin perbaikan kualitas sumber daya manusia di suatu negara (Leonard, 2015). Sebagai salah satu contoh, Finlandia merupakan salah satu negara yang memiliki sumber daya manusia yang terbaik dilihat dari prestasi belajar siswa secara internasional. Finlandia melakukan pengembangan potensi profesi guru melalui banyak metode salah satunya adalah mewajibkan para calon guru untuk melaksanakan pembelajaran ditingkat universitas melalui penelitian dan pelatihan pengembangan profesi (Adha, dkk., 2019). Di Indonesia kegiatan penelitian diwajibkan pada mahasiswa calon guru yang bertujuan untuk meningkatkan kemampuannya dalam memecahkan masalah. Namun, kenyataan dilapangan menunjukkan bahwa guru belum memiliki kompetensi yang memadai, salah satunya dalam hal penelitian (Leonard, 2015). Lebih lanjut Leonard (2015), untuk memiliki kompetensi penelitian yang memadai, harus ditunjang dengan pengetahuan dan keterampilan terkait penulisan karya ilmiah, karena dalam kegiatan penelitian, guru harus membacar berbagai refrensi bacaan dan harus mampu menuliskan hasil penelitiannya dalam bentuk karya tulis ilmiah yang sesuai dengan kaidah penulisan ilmiah.

Berdasarkan paparan di atas, secara umum kendala yang dialami guru dalam menulis artikel ilmiah diantaranya: 1) motivasi dan kesadaran untuk menulis ilmiah yang masih relatif rendah; 2) rendahnya pengetahuan tentang mencari referesni atau sumber dalam menyusun artikel ilmiah; 3) rendahnya kemampuan penulisan yang menyesuaikan gaya selingkung jurnal ilmiah yang dituju.

Sukarno (2017) menyarankan upaya-upaya yang dapat dilakukan oleh guru untuk mengembangkan profesionalisme dalam menulis karya ilmiah sebagai salah satu wujud pengembangan profesi adalah melalui: (a) mengikuti pelatihan/workshop, (b) belajar sendiri, (c) mengikuti lomba.

Menurut Noorjannah (2014), melalui pelatihan yang dilakukan secara berkala untuk guru-guru terkait dengan pengetahuan, pemahaman dan praktik menulis karya tulis ilmiah, dengan narasumber yang kompeten dibidangnya sehingga bisa memberi pengetahuan dan pemahaman yang jelas tentang karya tulis ilmiah. Selain itu, menurut Noorjannah (2014) kegiatan pelatihan dapat memotivasi guru untuk menulis karya ilmiah dalam upaya meningkatkan profesionalisme guru.

Berdasarkan paparan di atas, penulis ingin memberikan pengabdian kepada masyarakat, dalam bentuk "Pelatihan Penulisan Karya Ilmiah Bagi Guru-guru SMA Kecamatan Jalaksana Kabupaten Kuningan". Melalui pelatihan yang diawali denga paparan penjelasan tujuan kegiatan pelatihan penulisan artikel ilmiah, pentingnya kemampuan menulis artikel bagi guru, diharapkan dapat meningkatkan motivasi dan kemampuan guru dalam menulis artikel ilmiah. Selanjutnya pemberian tips dan trik menulis artikel ilmiah bagi guru, diantaranya, tips dan trik mencari sumber refrensi, Pemberian tips dan trik memilih tempat publikasi, tips dan trik mempublikasikan artikel ilmiah, dan teknis pelatihan penulisan artikel ilmiah diantaranya mengutip/mensitasi tulisan para ahli baik dari buku, maupun jurnal dan membuat/mendesain artikel ilmiah sesuai tamplate artikel jurnal yang dituju. Dengan harapan melalui kegiatan pelatihan ini guruguru membantu meningkatkan motivasi dan kemampuan guru dalam menulis artikel ilmiah dari hasil penelitian yang dapat digunakan sebagai salah satu persyaratan pengajuan kenaikan pangkat sehingga berdampak juga terhadap profesionalitas guru. 


\section{METODOLOGI PENGABDIAN}

Metode kegiatan ini berupa pelatihan penulisan artikel ilmiah kepada guru-guru. Setelah diberi pelatihan, selanjutnya guru-guru dibimbing untuk menerapkan hasil pelatihan dalam rangka meningkatkan kemampuan menulis artikel ilmiah.

Untuk melaksanakan kegiatan tersebut digunakan beberapa metode pelatihan, yaitu: 1) Metode Ceramah; 2) Metode Tanya Jawab; dan 3) Metode Simulasi. Metode ceramah dipilih untuk memberikan penjelasan dan memotivasi mahasiswa tentang pentingnya kemampuan menulis artikel ilmiah bagi guru. Metode tanya jawab sangat penting bagi para peserta pelatihan, baik di saat menerima penjelasan tentang cara penulisan artkel ilmiah serta saat praktik, Metode ini memungkinkan peserta menggali pengetahuan sebanyak-banyaknya tentang penulisan artikel ilmiah dan juga pengalaman setelah praktik simulasi menulis artikel ilmiah. Metode simulasi ini sangat penting diberikan kepada para peserta pelatihan untuk memberikan kesempatan mempraktekan materi pelatihan yang diperoleh. Harapannya, peserta pelatihan akan benar-benar menguasai materi pelatihan yang diterima, mengetahui tingkat kemampuannya menerapkan kegiatan penulisan artikel ilmiah secara teknis dan kemudian mengidentifikasi kesulitan-kesulitan (jika ada) untuk kemudian dipecahkan.

Evaluasi kegiatan dilakukan selama proses dan akhir pelatihan, pada aspek pencapaian tujuan pelatihan dan juga penyelenggaraan pelatihan. Evaluasi proses dan hasil (pencapaian tujuan pelatihan) dilakukan dengan dokumentasi. Sedangkan evaluasi aspek penyelenggaraan pelatihan dilakukan dengan pemberian angket. Indikator keberhasilan dalam pelaksanaan pelatihan pemanfaatan dan penulisan artikel ilmiah menggunakan 2 metode, yaitu: (1) Evaluasi selama proses pelatihan, dan (2) evaluasi pasca pelatihan.

Evaluasi saat pelaksanaan pelatihan meliputi, keterlibatan dan kemampuan peserta setiap tahap pelatihan. Pada Tahap akhir, peserta diharapkan dapat melakukan kegiatan penulisan artikel ilmiah yaitu : 1) Membuat kerangka tulisan (outline) sebuah artikel ilmiah; 2) Membuat kutipan (mengutip/mensitasi) tulisan para ahli baik dari buku, maupun jurnal; 3) Membuat/mendesain karya artikel ilmiah berdasarkan tamplate jurnal yang dituju.

Evaluasi Pasca Pelatihan, melalui pemberian angket terkait kebermanfaatan pelatihan penulisan artikel ilmiah bagi guru yang mengikuti pelatihan.

\section{PELAKSANAAN KEGIATAN}

Kegiatan Pengabdian berupa pelatihan penulisan artikel ilmiah dilaksanakan di SMA N 1 Jalaksana dengan peserta pelatihan guru-guru yang berasal dari SMA N 1 Jalaksana. Kegiatan pengabdian dilaksanakan yang dimulai dari tanggal 4 Oktober sampai dengan tanggal 18 Oktober 2019. Adapun kegiatan pelatihan Penulisan artikel yang dilakukan dalam setiap pertemuan akan diuraikan sebagai berikut:
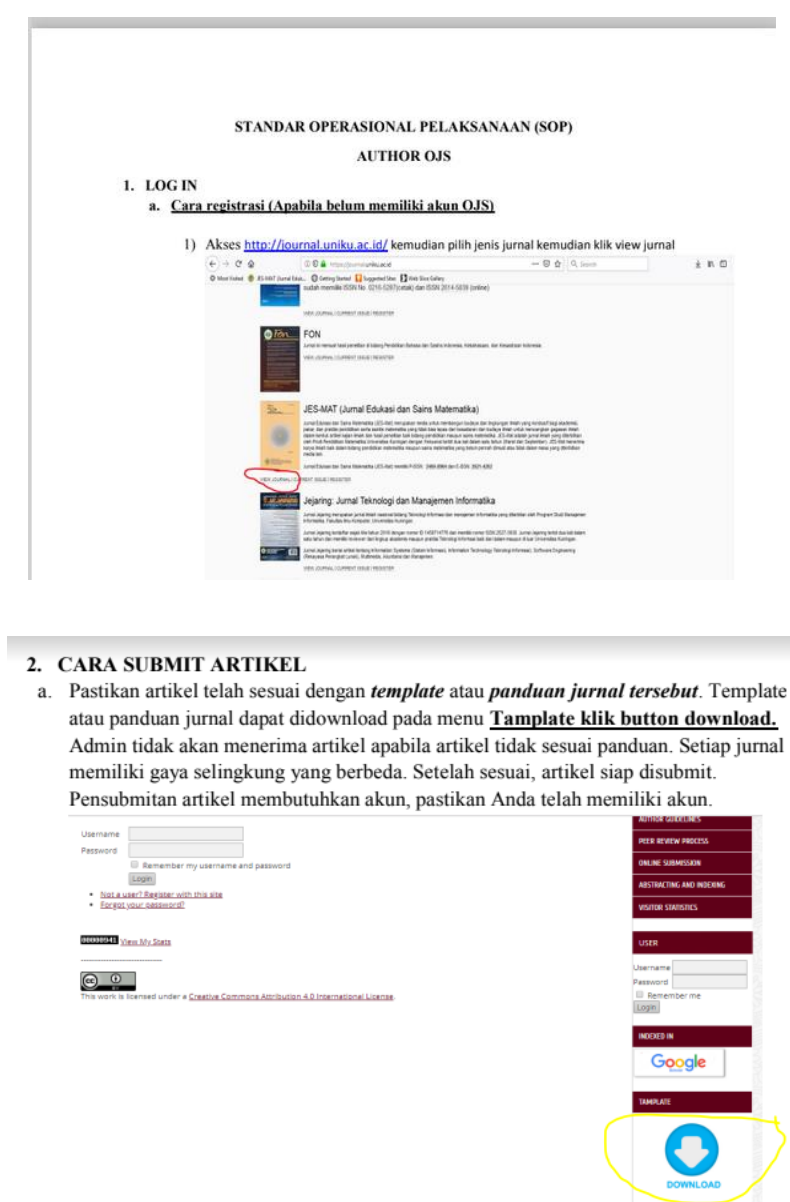

Gambar 2. Handout tata cara register dan submit artikel melalui OJS

\section{Tahap Persiapan}

Tahap persiapan yang dilakukan meliputi :

Penyusunan bahan/materi pelatihan, yang meliputi: handout beurpa tata cara register dan submit artikel melalui OJS; power point untuk kegiatan pelatihan penulisan artikel ilmiah. Gambar 2 adalah contoh 
materi pelatihan berupa handout tata cara register ddan submit artikel melalui OJS.

Gambar 3 adalah contoh materi pelatihan berupa power point untuk kegiatan pelatihan penulisan artikel ilmiah..

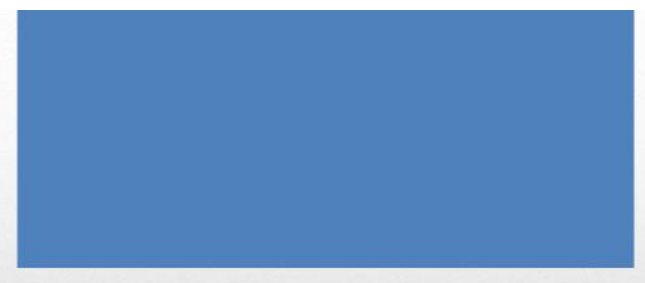

\section{PENULISAN ARTIKEL LMIAH}

UNTUK PENINGKATAN

PROFESIONALISME GURU

\section{Hakikat Artikel IImiah}

Hasil Perpaduan Penguasaan dan kemampuan:

- Substansi (Isi)

- Sistematika (bentuk/tata tulis dan alur)

- Bahasa

- Daya analisis

- Daya ungkap

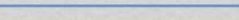

Gambar 3. Power point untuk kegiatan pelatihan penulisan artikel ilmiah

\section{Tahap Pelaksanaan Pelatihan}

Dalam tahap ini dilakukan pertama, penjelasan tentang pentingnya penulisan artikel ilmiah bagi guru, sesi pelatihan ini menitikberatkan pada pemberian penjelasan mengenai pentingnya pengetahuan dan kemampuan tentang penulisan artikel ilmiah untuk memotivasi guru dalam menulis artikel ilmiah; kedua, sesi pelatihan yang menitikberatkan pada praktik dalam memilih tempat publikasi yang sesuai, praktik mencari sumber refrensi mutakhir (terutama refrensi artikel-artikel jurnal) melalui google scholar, pemaparan tentang trik untuk publikasi artikel ilmiah hasil penelitian; ketiga, praktik simulasi menulis artikel ilmiah sesuai dengan tamplate jurnal yang dituju. Kegiatan ini dilakukan dengan teknik simulasi agar guru mendapatkan pengalaman langsung dan mendapat pengayaan dari sesama rekan guru dan tim pengabdian.

\section{Memberikan materi pelatihan}

Beikut deskripsi setiap pertemuan dari pelaksanaan pelatihan penulisan artikel ilmiah diuraikan sebagai berikut

\section{Pertemuan pertama}

Pertemuan pertama dilaksanakan pada 4 Oktober 2019. Pelatihan penulisan artikel ini dibuka oleh ketua pengabdian Sumarni, M.Pd, Kepala SMA N 1 Jalaksana dan Wakil Kepala SMA Jalaksana SMA N 1 Jalaksana. Peserta yang mengikuti kegiatan pelatihan ini berjumlah 21 orang guru SMA di Kecamatan Jalaksana, 16 orang guru dari SMA Jalaksan dan 5 orang guru dari salah satu MA swasta di Jalaksana. Peserta pelatihan terdiri dari beberapa guru bidang studi diantaranya, guru Matematika, guru Biologi, guru Bahasa Indonesia, guru Bahasa Inggris dan guru Ekonomi. Pada pertemuan pertama ini dilakukan pemberian penjelasan terkait tujuan kegiatan pelatihan penulisan artikel ilmiah, pentingnya kemampuan menulis artikel bagi guru.. hal ini penting sebagai upaya memotivasi guru untuk mau belajar menulis karya tulis ilmiah, dan meningkatkan keingintahuan guru tentang kemampuan menulis karya tulis ilmiah yang merupakan salah satu upaya bentuk pengembangan profesi dan karier serta sebagai upaya mengingkatakan kualitas profesionalitas sebagai pendidik dalam pembelajaran.

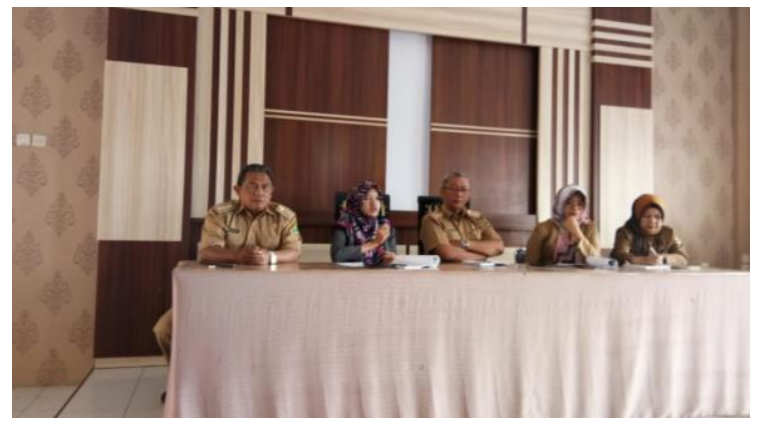

Gambar 4. Pemaparan untuk meningkatkan motivasi guru dalam menulis artikel ilmiah

Kemudian diinformasikan beberapa materi yang akan menjadi bahan dalam kegiatan pelatihan dan diinformasikan bahwa dalam pertemuan selanjutnya kegiatan pelatihan penggunaan dan pemanfaatan teknologi dan internet untuk memperoleh sumber sumber refrensi dan media publikasi karya tulis 
ilmiah yang dilaksanakan dengan praktik bersamasama antara dosen dan para peserta pelatihan. Gambae 4 adalah foto kegiatan pelatihan pada pertemuan pertama.

Pada pertemuan pertama para peserta pelatihan terlihat antusias dalam mengikuti kegiatan pelatihan dalam mengikuti pemberian informasi tentang tujuan kegiatan pelatihan penulisan artikel ilmiah, pentingnya kemampuan menulis artikel bagi guru. Para peserta pelatihan (guru-guru) mulai menunjukkan rasa keingintahuan terhadap tujuan kegiatan pelatihan penulisan artikel ilmiah, pentingnya kemampuan menulis artikel bagi guru sangat besar. Hal ini terlihat dari banyak peserta yang bertanya mengenai bagaimana agar guru-guru tersebut dapat mempunyai tulisan ilmiah yang dapat dijadikan syarat kenaikan pangkat guru.

\section{Pertemuan Kedua}

Pertemuan kedua ini berlangsung pada tanggal 11 Oktober 2019. Dosen menjelaskan kepada peserta pelatihan tentang materi yang akan dipelajari dan tujuan dari pelatihan pada pertemuan kedua yaitu tips dan trik menulis artikel ilmiah bagi Guru, diantaranya, tips dan trik mencari sumber refrensi, tips dan trik memilih tempat publikasi, tips dan trik mempublikasikan artikel ilmiah. Berdeda dengan pertemuan pertama yang lebih kepada pemberian motivasi terkait pentingnya kemampuan menulis artikel ilmiah untuk pengembangan karir dan profesi guru sebagai pendidik. Pertemuan kedua ini peserta pelatihan diberikan pengalaman proses mencari sumber refrensi artikel jurnal terkait topik penelitian masing-masing melalui Google Scholar.

Selain itu, peserta pelatihan juga mendapat informasi cara mencari media publikasi tulisan ilmiah sesuai dengan bidang kajian di wilayah Kuningan, Cirebon, Indramayu dan Majalengka, melalui website jurnal beberapa universitas dan sekolah tinggi diwilayah tersebut. Beberapa website jurnal yang diakses diantanya https://journal.uniku.ac.id/, http://jurnal.upmk.ac.id/, http://www.syekhnurjati.ac.id/jurnal/, http://jurnal.unswagati.ac.id/,

http://jurnal.unma.ac.id/, http://journal.unwir.ac.id/. Berikut foto kegiatan pelatihan pada pertemuan kedua.

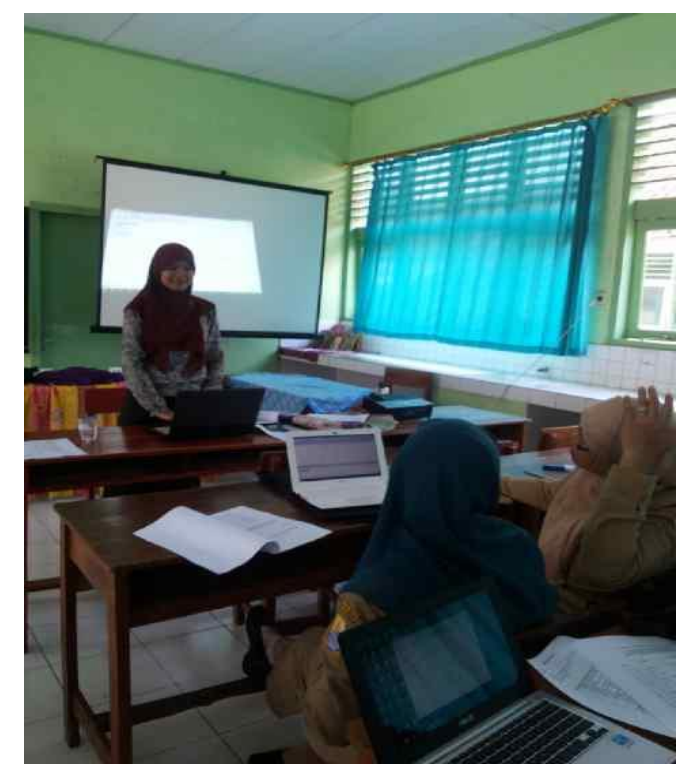

Gambar 5. Pemaparan tips dan trik menulis artikel ilmiah bagi Guru

\section{Pertemuan Ketiga}

Pertemuan ketiga ini berlangsung pada tanggal 18 Oktober 2019. Dosen menjelaskan kepada peserta pelatihan tentang teknis pelatihan penulisan artikel ilmiah diantaranya mengutip/mensitasi tulisan para ahli baik dari buku, maupun jurnal dan membuat/mendesain artikel ilmiah sesuai tamplate artikel jurnal yang dituju.

Pada kegiatan pelatihan ini, dosen mengambil contoh cara pengutipan dan format penulisan daftar pustaka berdasarkan sumber artikel yang terdapat di Google Scholar. Gambar 6 adalah salah satu contoh yang diberikan kepada peserta pelatihan.

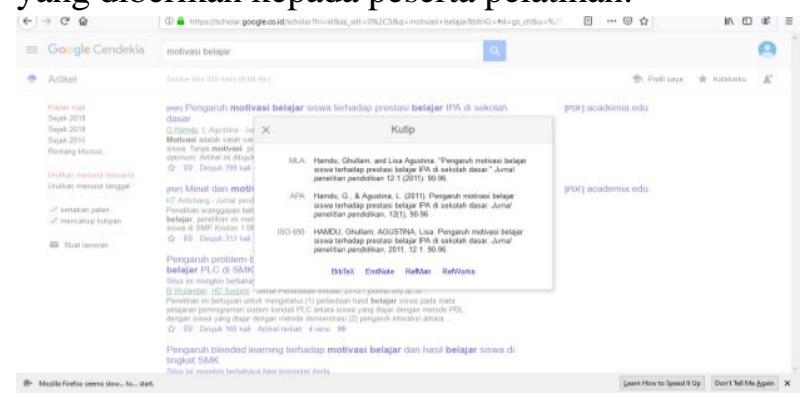

Gambar 6. Contoh cara menulis format daftar pustaka melalui Google Scholar

Selanjutya adalah aktivitas membuat/mendesain artikel ilmiah sesuai tamplate artikel jurnal yang dituju. Dalam aktivitas ini dosen memberikan contoh membuat artikel menggunakan tamplate artikel pada Jurnal Edukasi dan Sains Matematika (JES-MAT).

Selanjutnya adalah kegiatan simulasi dilakukan oleh dosen, untuk melakukan submit artikel pada jurnal yang dituju. Pada saat kegiatan submit artikel 
ke OJS, terdapat pertanyaan "apakah harus memiliki email?". Dosen memberikan jawaban bahwa email sangat diperlukan dalam penulisan artikel ilmiah, selain ddalam identitas artikel harus mencantumkan email, dalam submit artikel OJS juga harus mengisi alamat email penulis. Karena dalam OJS email berfungsi sebagai sarana komunikasi antara penulis, editor dan reviewer. Setelah di klarifikasi apakah bapak ibu peserta pelatihan seluruhnya sudah mempunyai email? Perserta pelatihan memberikan dua respon jawaban yaitu sudah, sudah pernah buat tapi lupa. Sehingga, hal ini membuat agak sedikit terhambat pada sesi simulasi membuat akun pada jurnal yang di tuju, untuk beberapa guru yang lupa email yang pernah dibuat. Berikut foto kegiatan pelatihan pada pertemuan ketiga.

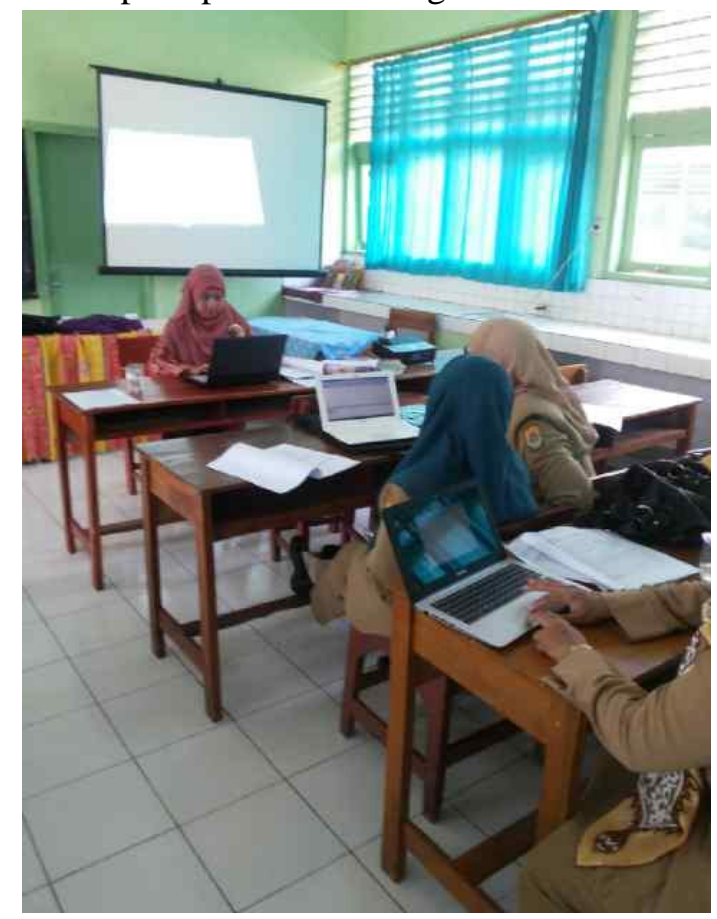

Gambar 6. Teknis pelatihan penulisan artikel ilmiah diantaranya mengutip/mensitasi

\section{HASIL DAN PEMBAHASAN}

Salah satu tujuan kegiatan pengabdian dalam betuk pelatihan penulisan artikel ilmiah bagi guru SMA ini adalah untuk meningkatkan motivasi guru untuk menulis artikel ilmiah. Hal tersebut berdasarkan permasalahan yang ditemukan oleh Supriyanto (2015), yang menyatakan salah satu kendala guru dalam menulis artikel ilmiah adalah motivasi menulis yang rendah. Paparan penjelasan terkait tujuan kegiatan pelatihan penulisan artikel ilmiah, pentingnya kemampuan menulis artikel bagi guru untuk kenaikan pangkat dan profesionalisme guru, pada pertemuan pertama dapat meningkatkan motivasi guru untuk menulis artikel ilmiah. Selain itu pemberian tips dan trik menulis artikel ilmiah, diantaranya tips dan trik memilih tempat publikasi, tips dan trik mencari sumber refrensi, tips dan trik mempublikasikan artikel ilmiah. Memberi

Supriyanto (2015) yang menyatakan bahwa: kendala yang dialami guru dalam menulis karya ilmiah meliputi: (a) motivasi menulis yang rendah, (b) tidak memiliki cukup waktu luang, (c) kurangnya pemahaman tentang teknik penulisan, (d) kesulitan mencari data, (e) gagap teknologi, (f) tidak memiliki buku referensi,

Melalui aktivitas pemberian contoh cara pengutipan dan format penulisan daftar pustaka berdasarkan sumber artikel yang terdapat di Google Scholar dan peserta pelatihan melakukan simulasi pengutipan dan menuliskan daftar pustaka dengan memanfaatkan Google Scholar Pengetahuan dan kemampuan guru memilih tempat publikasi yang sesuai, pengetahuan guru tentang cara mencari sumber refrensi mutakhir (terutama refrensi artikelartikel jurnal) melalui Google Scholar (Amin dkk, 2017).

Melaksanakan teknis pelatihan penulisan artikel ilmiah diantaranya mengutip/mensitasi tulisan para ahli baik dari buku, maupun jurnal dan membuat/mendesain artikel ilmiah sesuai tamplate jurnal yang dituju. Dalam pelaksanaan pengabdian ini, dosen memberikan contoh simulasi teknis penulisaan dan membuat artikel ilmiah menggunakan tamplate Jes-Mat Prodi pendidikan Matematika, Uniku. Tamplate tersebut dapat di dwnoload di https://drive.google.com/file/d/11_5rSeJQrD9dwev Wil9VBuGHgwNvwM_E/view. Pelatihan penulisan artikel untuk publikasi di jurnal ilmiah merupakan salah satu upaya pengembangan profesionalisme guru-guru dalam rangka persyaratan naik pangkat (Sedana, 2018).

Hasil angket pelatihan penulisan artikel ilmiah yang diisi oleh peserta pelatihan aspeknya/indikator angket meliputi pelaksanaan pelatihan kegiatan untuk memahami penulisan ilmiah. Data yang terkumpul selanjutnya di rekap untuk kemudian dilakukan analisis mengenai tingkat pelaksanaan pelatihan kegiatan untuk memahami penulisan 
ilmiah. Hasil rekapan data tingkat pelaksanaan pelatihan kegiatan untuk memahami penulisan ilmiah dapat dilihat pada tabel 1 berikut ini.

Tabel 1

Data Tingkat Pelaksanaan Pelatihan Kegiatan untuk Memahami Penulisan Ilmiah

\begin{tabular}{|c|c|c|c|c|c|c|}
\hline \multirow{2}{*}{ No. } & \multirow{2}{*}{ Pernyataan } & \multicolumn{4}{|c|}{ Jawaban } & \multirow{2}{*}{ Ket. } \\
\hline & & $\mathbf{0}$ & 1 & 2 & 3 & \\
\hline \multirow[t]{2}{*}{1.} & Pengetahuan tentang karya artikel ilmiah & 0 & 0 & 3 & 10 & $100 \%$ Positif \\
\hline & & $0 \%$ & $0 \%$ & $23 \%$ & $77 \%$ & \\
\hline \multirow[t]{2}{*}{2.} & Pengetahuan tentang cara menulis artikel & 0 & 0 & 7 & 6 & $100 \%$ Positif \\
\hline & ilmiah & $0 \%$ & $0 \%$ & $54 \%$ & $46 \%$ & \\
\hline \multirow[t]{2}{*}{3.} & Pengetahuan tentang manfaat menulis & 0 & 0 & 1 & 12 & $100 \%$ Positif \\
\hline & artikel ilmiah & $0 \%$ & $0 \%$ & $8 \%$ & $92 \%$ & \\
\hline \multirow[t]{2}{*}{4.} & Pengetahuan tentang memilih tempat & 0 & 0 & 9 & 4 & $100 \%$ Positif \\
\hline & publikasi artikel ilmiah & $0 \%$ & $0 \%$ & $69 \%$ & $21 \%$ & \\
\hline \multirow[t]{2}{*}{5 . } & Pegetahuan tentang cara mencari sumber & 0 & 0 & 2 & 11 & $100 \%$ Positif \\
\hline & refrensi & $0 \%$ & $0 \%$ & $15 \%$ & $85 \%$ & \\
\hline \multirow[t]{2}{*}{6.} & Pengetahuan tentang cara mensitasi & 0 & 0 & 4 & 9 & $100 \%$ Positif \\
\hline & $\begin{array}{l}\text { tulisan/ide para ahli dari buku maupun } \\
\text { jurnal }\end{array}$ & $0 \%$ & $0 \%$ & $21 \%$ & $69 \%$ & \\
\hline \multirow[t]{2}{*}{7.} & Pengetahuan tentang cara membuat & 0 & 0 & 8 & 5 & $100 \%$ Positif \\
\hline & kerangka tulisan/outline & $0 \%$ & $0 \%$ & $62 \%$ & $38 \%$ & \\
\hline \multirow[t]{2}{*}{8.} & Pengetahuan tentang mendesian karya & 0 & 0 & 7 & 6 & $100 \%$ Positif \\
\hline & artikel ilmiah & $0 \%$ & $0 \%$ & $54 \%$ & $46 \%$ & \\
\hline \multirow[t]{2}{*}{9.} & Pemahaman tentang karya artikel ilmiah & 0 & 0 & 7 & 6 & $100 \%$ Positif \\
\hline & & $0 \%$ & $0 \%$ & $54 \%$ & $46 \%$ & \\
\hline \multirow[t]{2}{*}{10.} & Pemahaman tentang cara menulis artikel & 0 & 0 & 5 & 8 & $100 \%$ Positif \\
\hline & ilmiah & $0 \%$ & $0 \%$ & $38 \%$ & $52 \%$ & \\
\hline \multirow[t]{2}{*}{11.} & Pemahaman tentang manfaat menulis artikel & 0 & 0 & 7 & 6 & $100 \%$ Positif \\
\hline & ilmiah & $0 \%$ & $0 \%$ & $54 \%$ & $46 \%$ & \\
\hline \multirow[t]{2}{*}{12.} & Pengetahuan tentang memilih tempat & 0 & 0 & 7 & 6 & $100 \%$ Positif \\
\hline & publikasi artikel ilmiah & $0 \%$ & $0 \%$ & $54 \%$ & $46 \%$ & \\
\hline \multirow[t]{2}{*}{13.} & Pemahaman tentang cara mencari sumber & 0 & 0 & 9 & 4 & $100 \%$ Positif \\
\hline & refrensi & $0 \%$ & $0 \%$ & $69 \%$ & $31 \%$ & \\
\hline \multirow[t]{2}{*}{14.} & Pemahaman tentang cara mensitasi & 0 & 0 & 12 & 1 & $100 \%$ Positif \\
\hline & $\begin{array}{l}\text { tulisan/ide para ahli dari buku maupun } \\
\text { jurnal }\end{array}$ & $0 \%$ & $0 \%$ & $92 \%$ & $8 \%$ & \\
\hline \multirow[t]{2}{*}{15.} & Pemahaman tentang cara membuat kerangka & 0 & 0 & 9 & 4 & $100 \%$ Positif \\
\hline & tulisan/outline & $0 \%$ & $0 \%$ & $69 \%$ & $31 \%$ & \\
\hline \multirow{6}{*}{16.} & Pemahaman tentang mendesian karya artikel & 0 & 0 & 7 & 6 & $100 \%$ Positif \\
\hline & ilmiah & $0 \%$ & $0 \%$ & $54 \%$ & $46 \%$ & \\
\hline & Ket: & 0 & \multirow{2}{*}{\multicolumn{3}{|c|}{ : Tidak bermanfaat }} & \\
\hline & & 1 & & & & \\
\hline & & 2 & \multicolumn{3}{|c|}{ : Bermanfaat } & \\
\hline & & 3 & \multicolumn{3}{|c|}{ : Sangat bermanfaat } & \\
\hline
\end{tabular}

Berdasarkan rekap hasil angket kebermanfaatan kegiatan pelatihan penulisan ilmiah, pada tabel 1 dapat terlihat bahwa peserta pelatihan memberikan respon bahwa kegiatan pelatihan penulisan artikel ilmiah yang dilakukan bermanfaat dan sangat bermanfaat bagi mereka.
Peserta yang berjumlah 21 orang guru, 2 orang berhasil mencoba submit artikel yang ditulisnya pada jurnal yang dituju, 7 orang berhasil membuat tulisan berupa artikel ilmiah sesuai tamplate jurnal yang dituju dan 12 orang hanya mampu membuat 
draft kasar artikel tulisan ilmiah yang masih kurang sesuai dengan tamplate jurnal yang dituju.

\section{PENUTUP}

\section{Kesimpulan}

Berdasarkan hasil kegiatan pengabdian, dapat diambil kesimpulan sebagai berikut:

1. Pemaparan penjelasan terkait tujuan kegiatan pelatihan penulisan artikel ilmiah, pentingnya kemampuan menulis artikel bagi guru untuk kenaikan pangkat dan profesionalisme guru, pada pertemuan pertama dapat meningkatkan motivasi guru untuk menulis artikel ilmiah. Hal ini terbukti seluruh peserta mau mencoba belajar menulis artikel ilmiah secara bersama sama dan antusias dalam mengikuti kegiatan pelatihan.

2. Guru memiliki pengetahuan dan kemampuan memilih tempat publikasi yang sesuai, melalui kegiatan sesi pelatihan yang menitikberatkan pada praktik dalam memilih tempat publikasi yang sesuai, hal ini terbukti dari jurnal yang dituju dan tamplate artikel jurnal dari draft tulian ilmiah sesuai dengan bidang studi guru, misal guru matematika mencoba menulis draft artikel ilmiah pada Jurnal Mathline, JES-MAT.

3. Guru memiliki pengetahuan tentang cara mencari sumber refrensi mutakhir (terutama refrensi artikel-artikel jurnal) melalui google scholar, melalui sesi kegiatan praktik mencari sumber refrensi mutakhir (terutama refrensi artikel-artikel jurnal) melalui google scholar, terbukti melalui praktik bersama guru mencoba mencari dan memperoleh beberapa refrensi artikel yang terkait tulisan masing masing melalui pencarian di google scholar.

4. Guru memiliki pengetahuan tentang trik untuk publikasi artikel ilmiah hasil penelitian melalui sesi kegiatan pemaparan tentang trik untuk publikasi artikel ilmiah hasil penelitian, hal ini terbutki dengan beberapa darft tulisan artikel ilmiah yang dibuat guru telah mengikuti gaya penulisan jurnal yang dituju.

5. Peserta pelatihan penulisan artikel ilmiah dalam hal ini guru-guru tingkat SMA di Kec. Jalaksana, Kab. Kuningan memiliki pandangan positif terhadap kegiatan pelatihan penulisan artikel ilmiah, guru-guru memandang bahwa tingkat kebermanfaatan kegiatan pelatihan ini pada tingkat bermanfaat dan sangat bermanfaat. Hal ini berdasarkan hasil angket respon terhadap kegiatan pelatihan, peserta pelatihan memberikan respon bahwa kegiatan pelatihan penulisan artikel ilmiah yang dilakukan bermanfaat dan sangat bermanfaat bagi mereka.

\section{Saran}

Berdasarkan kegiatan pelatihan penulisan artikel ilmiah guru-guru tingkat SMA di Kec. Jalaksana, Kab. Kuningan yang telah dilakukan, penulis memberikan saran-ssaran sebagai berikut.

1. Temuan dilapangan menunjukkan masih terddapat beberapa guru yang lupa akun email. Email menjadi salah satu yang wajib dimiliki oleh penulis dalam menulis artikel, selain itu email merupakan sarana komunikasi dalam publikasi artikel ilmiah. Sehingga diharapkan sebelum pelatihan penulisan artikel ilmiah, bagi peserta yang lupa akun email dibimbing terlebih dahulu untuk membuat akun email dan menyarankan agar username dan pasword email yang telah dibuat di save di memo hape masing masing agar ketika lupa bisa dilihat kembali.

2. Pada kegiatan pengabidan ini karena keterbatasan waktu, sehingga kegiatan simulasi menulis artikel ilmiah sesuai dengan tamplate jurnal yang dituju tidak bisa dikuti oleh seluruh peserta, jadi pada kegiatan pengabdian ini, peserta hanya melihat dosen memberikan contoh simulasi membuat artikel jurnal. Untuk pengabdian berikutnya diharapkan dapat memberikan pengalaman kepada peserta untuk melakukan simulasi menulis artikel jurnal berdasarkan hasil penelitian yang telah dilakukan oleh setiap guru sebagai peserta pelatihan.

\section{Ucapan Terima Kasih}

Penulis mengucapkan terimakasih kepada Universitas Kuningan, selaku pemberi dana pengabdian, melalui hibah pengabdian internal tahun anggaran 2019 dalam pelaksanaan kegiatan pengabdian ini. 


\section{DAFTAR PUSTAKA}

Adha, M., A., Gordisona, S., Ulfatin, N., Supriyanto, A. 2019. Analisis Komparasi Sistem Pendidikan Indonesia dan Finlandia. Tabdir: Jurnal Studi Manajemen Pendidikan. 3 (2): 145160.

Daryanto. 2013. Standar Kompetensi danPenilaian Kinerja Guru Profesional. Yogyakarta: Gava Media.

Gunawan, I., Triwiyanto, T., Kusumaningrum, D. E. 2017. Laporan Pengabdian Pendampingan Penulisan Artikel Ilmiah Bagi Para Guru Sekolah Menengah Pertama Negeri Kecamatan Lowokwaru Kota Malang. Laporan Pengabdian Kepada masyarakat PNBP. Malang:Tidak diterbitkan.

Leonard. 2015. Kompetensi Tenaga Pendidik di Indoensia: Analisis Dampak Rendahnya Kualitas SDM Guru dan Solusi Perbaikannya. Jurnal Formatif. 5 (3): 192-201.

Mawardi, Kristin, F., Anugraheni, I., Rahayu, T., S. 2019. Penerapan Pelatihan Partisipatif pada Kegiatan Penulisan dan Publikasi Karya Ilmiah bagi Guru SD. Scholaria: Jurnal Pendidikan dan Kebudayaan. 9 (2): 1132-137.

Mujiwati, E.S dkk. 2017. Pelatihan Penulisan Karya Ilmiah untuk Guru Sekolah Dasar pada anggota Gugus 1 Kecamatan Ringinrejo Kabupaten Kediri. Jurnal ABDINUS. 1 (1): 53-68.

Noorjannah, L. 2014. Pengembangan Profesionalisme Guru melalui Penulisan Karya Tulis Ilmiah bagi Guru Profesional di SMA Negeri 1 Kauman Kabupaten Tulungagung. Jurnal Humanity. 10 (1): 97-104.

Permen PAN dan RB No. 16. 2009. Tentang Jabatan Fungsional Guru dan Angka Kreditnya

Rintaningrum, R. 2018. Mengapa Guru tidak Menulis Karya Ilmiah: Perspektif Guru. Prosiding Seminar Nasional Bahasa, Sastra dan Pendidikan dalam Perspektif Masyarakat Ekonomi ASEAN (MEA): Program Studi Pendidikan Bahasa dan Sastra Indonesia Fakultas Ilmu Pendidikan Universitas Trunojoyo Madura. 60-68.

Samuel. M. 2012. Working in the rain: pressures and priorities for teacher education curriculum design in South Africa: a case-study of the University of Durban-Westville inResearching Teacher Education: The Multi-Site Teacher Education Project. Special Issue of the
International Journal of Educational Development, 22 (34): 57-66

Arta, K., S. 2018. Pelatihan Penulisan artikel untuk Publikasi di Jurnal Ilmiah untuk Meningkatkan Profesionalisme bagi Guru-guru di Kecamatan Kubutambahan Kabupaten Buleleng. Prosiding Seminar Nsional Hukun dan Ilmu Sosial Ke-2. Hal. 146-159.

Supriyanto, A. 2015. Harapan, Kenyataan dan Strategi Peningkatan Kemampuan Guru Dalam Penulisan Karya Tulis Ilmiah. Prosiding Seminar Nasional Pengembangan Keprofesian menuju Guru Profesional di Universitas Negeri Malang. 109-114. 